\title{
1P53 over expression in skin lesions: An immunohistochemical study
}

\begin{tabular}{ccc}
\hline Salah A. Ali * & Yusra Abdulkhaliq Qasim * & Jawhar Taher Omar * \\
\hline Abstract &
\end{tabular}

Background and objective: Immunohistochemistry is the application of immunologic principles and techniques to demonstrate molecules in cells and tissues. Gene p53 is a tumor-suppressor gene. The product of this gene is a nuclear protein thought to be involved in the control of the cell cycle, apoptosis, and the maintenance of genomic stability. Gene p53 is the most frequently mutated tumor suppressor gene found in human cancer. The aim of this study was to investigate p53 protein over expression in skin cancer and compare it with benign skin lesion.

Methods: A retrospective study was conducted on paraffin block from skin biopsy of 36 patients with various skin lesions; eight benign cases and 28 malignant cases. The sample of patients was collected from the Pathology Laboratory in Rizgary Teaching Hospital in Erbil, Kurdistan region, Iraq from December 2011 to December 2012. The age of the patients ranged from 34 to 80 years. The p53 protein over expression was investigated by immunohistochemical staining. Sample sections were stained and scored.

Results: Nineteen out of $28(76.8 \%)$ skin cancer showed over expression of p53 gene compared with benign skin lesion and there was a statistically significant difference. There was statistical significant difference in relation to the age group of patients with various skin cancers which was higher in patient above 40 years.

Conclusion: Increased expression of p53 a nuclear protein can be detected in human skin cancer compared with benign skin lesion and it may play an important role in pathogenesis of many types of skin cancers.

Keywords: Immunohistochemistry, Tumor Suppressor gene (p53) protein and skin cancers.

\section{Introduction}

Mutation of the p53 gene represents the most common genetic alteration in human tumors. The accumulation of the protein can also occur as a result of epigenetic changes, and therefore it is not an obligatory indicator of a gene mutation. ${ }^{1}$ P53 protein has an intracellular half-life of only 20 minutes. ${ }^{1}$ It is present at very low concentration below the limit of Immunohistochemical detection in most untransformed cells and non neoplastic tissue. $^{2}$ The altered protein product of the mutant gene has a much extended half-life and can be detected with immunohistochemical techniques. ${ }^{1}$ Epidemiological data strongly implicate sunlight as the principal environmental cause of skin cancer. $^{3}$ Sunlight acts as tumorigenic mutagen, it also acts as tumor promoter by favoring the clonal expansion of p53-mutated cells. These combined actions of sunlight result in normal individuals carrying a substantial burden of keratinocytes predisposed to cancer. ${ }^{4}$ The role of sunlight is supported by the finding of sunlight-induced mutations in the p53 tumor suppressor gene in actinic keratosis. The precancerous lesion for squamous cell carcinoma of the skin and other precancerous conditions is squamous-cell carcinoma in situ. ${ }^{4,5}$ It may progress to invasive disease if not treated completely. 6,7 The thickness of the epidermis and skin color are known to * Department of pathology, college of medicine, Hawler Medical University, Erbil, Iraq. 
attenuate the amount of UV light that reaches the basal layer of the epidermis and these factors may modify the distribution of p53 expression in the upper and basal layers of the epidermis. ${ }^{8,9}$ The aim of the study is to investigate p53 protein over expression in malignant skin lesions and compare it with the benign skin lesions and to evaluate the frequency rate of p53 expression measured in biopsies from various skin cancers.

\section{Methods}

This is a retrospective study conducted on paraffin block from skin biopsy of 36 patients with various skin lesions including 8 benign lesions and 28 malignant cases. The sample of patients was collected from the Pathology Laboratory in Rizgary Teaching Hospital in Erbil, Kurdistan region, Iraq for the period from December 2011 to December 2012. The age of the patients ranged from 34 to 80 years. Ethical approval was obtained from the Ethical Committee of Hawler Medical College. Immunohistochemical staining method was carried out on these samples using the DO-7 monoclonal antibody (Novocastra Laboratories, Newcastle upon Tyne, United Kingdom) at a 1:50 dilution using microwave antigen retrieval. All slides were counterstained with hematoxylin and examined at 400 magnification. For each case, a negative control section was examined to monitor staining quality based on the level of nonspecific background staining. The negative control section was prepared identical as the test section except that no primary antibody was placed over the slide. All 10-12 other procedures were the same. The distribution of p53 immunoreactivity in epidermal cells in which the nucleus was stained brownishred, including keratinocytes and melanocytes, were interpreted as p53positive cells. The examination and interview were done by three pathologists. P53 immunoreactivity were assessed by the proportion score (percentage) of p53-positive cells in the whole epidermis. The results were quantified by expressing the number of positive keratinocytes as a percentage of 1000 cells counted in each section. ${ }^{11-13}$ Tumor cells with staining $<10 \%$ were regarded as negative and $>10 \%$ were considered positive. ${ }^{3}$ Tumor staining pattern was divided into 5 categories (nil, <10\%, 10-20\%, 21-50\%, $>50 \%$ ). The proportional score of positively staining cells in each tumor was recorded as $(10-20 \%=+),(21-50 \%=++)$ and $(>50 \%=+++)$ but was classified as either p53-positive or p53-negative for analysis.

\section{Statistical Analysis:}

Statistical parameters as mean, standard deviation, t-test, z-test and chi-square test were used in the study. $P$ value $\leq 0.05$ was regarded as significant, values $<0.01$ were regarded as highly significant.

\section{Results}

There was statistical significant value in relation to age group examined in patients with various skin cancers which was higher in patient aged more than 40 years versus less than 40 years as shown in Table 1.

Table 1: Age distribution in relation to various skin lesions.

\begin{tabular}{llllllllll}
\hline $\begin{array}{l}\text { Age group } \\
\text { (Year) }\end{array}$ & \multicolumn{2}{l}{ Benign } & \multicolumn{3}{l}{ B.C.C } & \multicolumn{3}{l}{ S.C.C } & \multicolumn{2}{c}{ Melanoma } & P \\
& No. & $\%$ & No. & $\%$ & No. & $\%$ & No. & $\%$ & value \\
\hline$<40$ & 6 & 16.6 & 1 & 2.7 & 1 & 2.7 & 2 & 5.5 & 0.04 \\
$>40$ & 2 & 5.5 & 9 & 25 & 9 & 25 & 6 & 16.6 & \\
\hline
\end{tabular}


Regarding gender, there was no statistical significant difference in different type of skin cancer (Table 2). The p53 immunoreactivity of the skin lesions of the total 36 collected sample from patients with various skin lesions is shown in Table 3. The IHC expression of p53 in malignant cases was positive in only 19 of total 28 cases $(76.8 \%)$. The samples with most biopsies showed medium to intense p53-positive cells (Table 4); positive staining constituted $68.4 \%$ while negative $32.4 \%$.

\section{Discussion}

Recently p53 mutation has been implicated in the pathogenesis of many skin cancer. ${ }^{14}$ Most of these mutations are acquired, not inherited. ${ }^{15}$ Assessment of p53 status in human cells can be performed by immunohistochemical detection of nuclear p53 accumulation giving a rapid preliminary indication of $p 53$ status in tumors. ${ }^{16}$ Most skin cancers in the present study occur in old age group above 40 year. Age is considered to be a determinant of the neoplastic process. ${ }^{17}$ Other studies agree that skin cancers typically arise in patients aged $50-70 .{ }^{4}$ Differences in the estimation of p53 cut off value level in different studies account for some of the variability as some studies consider benign skin lesion as being positive. ${ }^{18}$ In the current study there was scattered discrete immunreactivity of p53 staining in keratinicytes which are considered as negative (the cut off value in present study $>10 \%$ ) In the current study there was statistical significant difference in p53 expression in patients with skin cancer compared with benign skin lesion. One investigator found that higher p53 immunoreactivity in the malignant cases. ${ }^{19}$ The observed staining pattern in our study were scattered in basal layer of epidermis in benign skin, but in BCC, SCC, cutaneous melanoma there was intense diffuse staining throughout the lesion. P53 staining intensity among malignant cases, shows statistically significant association most biopsies showing medium to intense

Table 2: Gender factor in relation to various skin lesion.

\begin{tabular}{llllll}
\hline Gender & Benign & B.C.C & SCC & Melanoma & $\boldsymbol{P}$ value \\
\hline Male & 3 & 3 & 8 & 4 & 0.103 \\
Female & 5 & 7 & 2 & 4 & \\
\hline
\end{tabular}

Table 3: Number of positive and negative p53 immunoreactivity cases.

\begin{tabular}{llllllll}
\hline Pathological Diagnosis & \multicolumn{2}{l}{ Positive $p 53$} & \multicolumn{2}{l}{ Negative $p 53$} & \multicolumn{2}{l}{ Total cases } & Statistic \\
& No. & $\%$ & No. & $\%$ & No. & $\%$ & Mean \pm S.E \\
\hline Benign & - & 0 & 8 & 22.3 & 8 & 22.3 & $1.3572 \pm 0.09132$ \\
Malignant melanoma & 5 & 13.9 & 3 & 8.33 & 8 & 22.3 & $1.0335 \pm 0.27631$ \\
Squamous cell carcinoma & 7 & 19.4 & 3 & 8.33 & 10 & 27.7 & $1.3521 \pm 0.24709$ \\
Basal cell carcinoma & 7 & 19.4 & 3 & 8.33 & 10 & 27.7 & $1.2560 \pm 0.27877$ \\
Total & 19 & 52.7 & 17 & 47.3 & 36 & 100 & \\
\hline
\end{tabular}

Table 4: P 53 immunohistochemistry proportional scoring intensity.

\begin{tabular}{llll}
\hline P53 scoring & $\mathbf{1 0 - 2 0 \% = +}$ & $\mathbf{2 1 - 5 0 = + +}$ & $\mathbf{> 5 0 = + + +}$ \\
\hline Number of cases & $3(15.8 \%)$ & $3(15.8 \%)$ & $13(68.4 \%)$ \\
\hline $\boldsymbol{P}$ value less than $\mathbf{0 . 0 5}$ is significant & & \\
\hline
\end{tabular}


http://dx.doi.org/10.15218/zjms.2015.0037

p53-positive cells, positive staining constituted $68.4 \%$. In the present study p53 over expression was detected in $70 \%$ of BCC, $70 \%$ of SCC and $83 \%$ in M.M. while variable results was found in other studies that $90 \%$ of squamous cell carcinoma and approximately $50 \%$ of basal cell carcinomas, and $20 \%$ of melanomas. ${ }^{5-7}$ This variability is due to small sample size in this study. The prevalence of abnormal p53 expression in series of invasive melanomas from Queensland was $83 \%$. Estimates of p53 expression vary widely, due to in part the differing characteristics of the antibodies used for detection and the criteria used for determining positive staining. ${ }^{17}$ In addition, individuals exhibit heterogeneity in their ability to repair DNA damage induced by UV radiation. This heterogeneity will affect the relationship between sun exposure and p53 mutation. ${ }^{20}$

\section{Conclusion}

Increased expression of p53 protein can be detected in human skin cancer compared with benign lesion and mutation of p53 may form an important part of pathogenesis of many type of skin cancer.

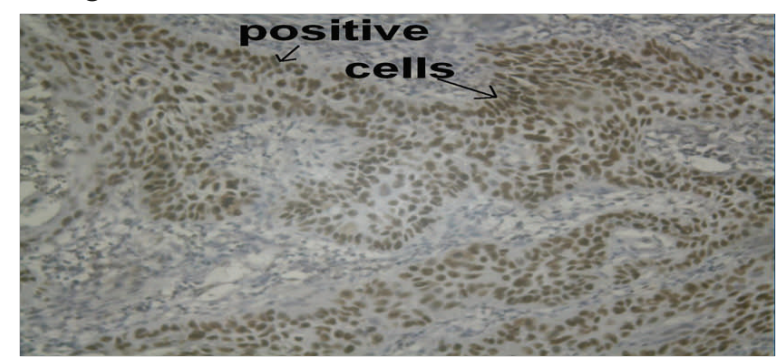

Figure 1: Basal cell carcinoma of skin IHC staining for p53 magnifideX400.

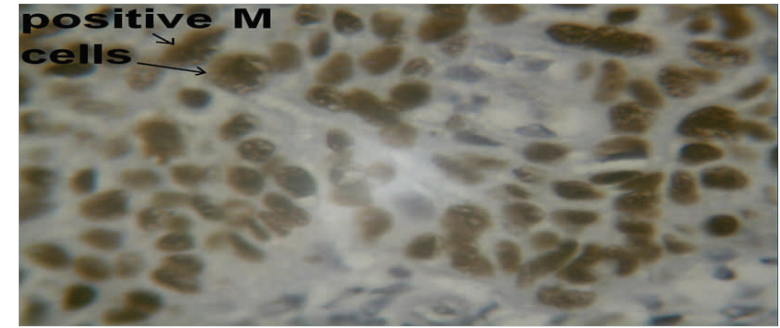

Figure 2: Squamouse cell carcinoma of skin IHC staining for p53 magnifideX400.

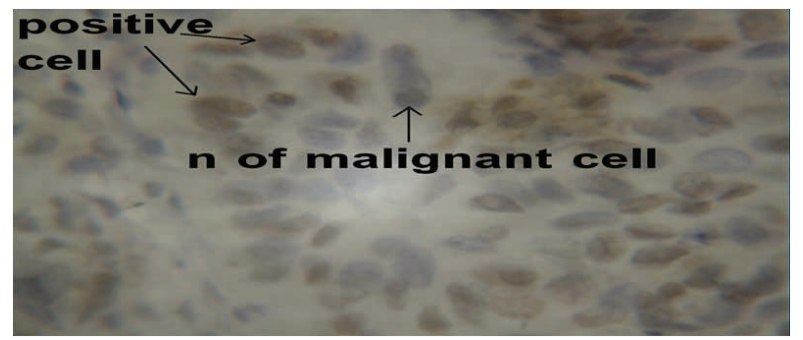

Figure 3: Malignant melanoma of skin IHC staining for p53 magnifideX400.

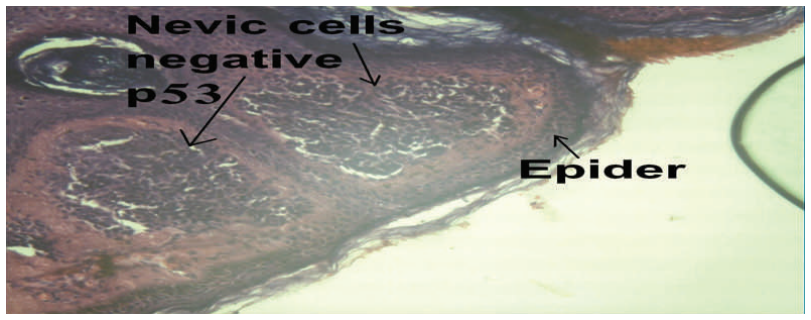

Figure 4: Intradermal nevus stained by IHC for p53 negative magnified X400. 


\section{Conflicts of interest}

The authors report no conflicts of interest.

\section{References}

1. Chan J KC. P53 expression. Rosai and Ackerman's Surgical Pathology. $10^{\text {th }}$ Edition. New York, SA: Mosby Elsever; 2011. PP 58.

2. Purdie CA, Grady J, Piris J, Wylie AH, Biral. P53 expression in colorectal cancer. AJP 1991; 138 (4):22-7.

3. Ghaderi R, Haghighi F. Immunohistochemistry assessment of $\mathrm{p} 53$ protein in basal cell carcinoma. Iran J Allergy Asthma Immunol 2005; 4(4):167-71.

4. Kricker A, Armstrong B K, English DR, Heenan PJ. Pigmentary and cutaneous risk factors for nonmelanocytic skin cancer a case control study. Int J Cancer 1991; 48(5):650-62.

5. Marisa RN, Christopher PC. In Mills SE Carter D, Greenson JK, Reuter VE and stoler MH, Editors. Sternberg. Non melanocytic cutaneous tumor. Diagnostic Surgical Pathology. 5th Edition. Baltimore USA: Lippinvott Williams and Wilkins; 2010. PP46-60.

6. Dinehart SM, Nelson-Adesokan P, Cockerell C, Russell S, Brown R. Metastatic cutaneous squamous cell carcinoma derived from actinic keratosis. Cancer 1997; 79(38):920-3.

7. Johnson TM, Rowe DE, Nelson BR, Swanson NA. Squamous cell carcinoma of the skin (excluding lip and oral mucosa).Journal American Acad Dermatol 1992; 26(5):467-84.

8. Agar NS, Halliday GM, Bametson RS .The basal layer in human squamous tumors harbors more UVA than UVB fingerprint mutations: A role for UVA in human skin carcinogenesis. Proc Natl Acad Sci USA 2004; 101(16):4954-9.

9. Shea CR, McNutt NS, Volkenandt M, Lugo J, Prioleau PG, Albino AP. Overexpression of p53 protein in basal cell carcinomas of human skin. Am J Pathol 1992; 141(1):25-9.

10. SoiniY, Kamel D,Pääkkö PLethtoV-P,Oikarinen A, VähäkangasK. Aberrant accumulation of p53 associates with Ki67 and mitotic count in benign skin lesions. British J Dermatol 1994; 131(4): 514-20.

11. Brown DC, Gatter KC. Ki67 protein: The immaculate deception? Histopathol 2002; 40(1): 2-11.

12. Shimuzu $T$, Oga A, Murakami T, Muto $M$ Overexpression of p53 protein associated with proliferative activity and histological degree of malignancy in solar keratosis. Dermatol 1999; 28 (6):113-8

13. Hermeking $\mathrm{H}$, Eick D. Mediation of c-Mycinduced apoptosis by p53. Science 1994; (26) 5:2091-3.

14. Shimuitzu T, Muto $M$, Murakami T, Furumoto $H$ Mogami S, Asagami C. Over expression of p53 protein associated with proliterative activity as evaluated by $\mathrm{Ki}-67$ immunostaining in well-differentiated squamous cell carcinoma of the skin. Dermatol 1997; 195(3):224-7.

15. Ringer DP, Schniper LE. Principles of cancer biology. Gene mutation that can lead to cancer. In: Lenhard RE, Osteen RT, Gansler T. Clinical Oncology. Atlanta, GA: American Cancer Society; 2001: 25- National Cancer Institute. Understanding Gene Testing. Accessed at http://www.cancer.gov/cancertopics/ understandingcancer/genetesting on 12/13/2011.

16. Sidransky D, Hollstein M. Clinical implications of the p53 Gene. Annu Rev Med 1996; 47(3): 285-301.

17. Whiteman DC, Parsons PG, Green AC. p53 expression and risk factors for cutanous melanoma: A case control-study. Int J Cancer 1998; 77 (6):843-8.

18. Jonason AS1, Kunala S, Price GJ, Restifo RJ, Spinelli HM, Persing JA, et al. Frequent clones of p53-mutated keratinocytes in normal human skin. Proc Natl Acad Sci USA 1996; 93 (24):14025-9.

19. Batinac PT, Zamolo G, Jonjic N, Gruber F, Petroveckj M. P53 protein expression and cell proliferation in non neoplastic and neoplastic proliferative skin diseases. Tumori 2004; 90 (6):120-7.

20. Ouhtit A, Nakazawa $H$, Yamasaki $H$, Armstrong BK, Kricker A, Tan E, et al. UV-radiation-specific p53 mutation frequency in normal skin as a predictor of risk of basal cell carcinoma. J Natl Cancer Inst 1998; 90(7):523-31. 